\title{
SEASONAL CHANGES IN THE PHYTO- PLANKTON DURING THE YEAR I95I-52 AS INDICATED BY SPECTROPHOTOMETRIC CHLOROPHYLL ESTIMATIONS
}

\author{
By W. R. G. Atkins, F.R.S. \\ and Pamela G. Jenkins \\ The Plymouth Laboratory \\ (With Text-figs. I-8)
}

In a previous paper (Atkins \& Parke, 195I) the phytoplankton was studied by the collodion filtration of $20 \mathrm{l}$. samples, the extraction of the filter disk with $80 \%$ aqueous acetone and the comparison of the extracts in a Kober colorimeter against each other and a commercial chlorophyll preparation. The interference of pigments other than chlorophyll was eliminated or much reduced by the use of a Schott RG I filter, which we subsequently found had previously been thus used by Rohde (I948). There was, however, frequently a delay in the filtration of our large samples and an increase in accuracy was desirable.

For the present work we were fortunate in having a Unicam spectrophotometer with $4.0 \mathrm{~cm}$. rectangular glass vessel for which $10 \mathrm{ml}$. of extract sufficed. This was prepared usually the day after the water had been collected, and I or 21 . of water were sufficient, according to season. Unfortunately, the $4 \mathrm{~cm}$. vessels got broken, so for a time $\mathrm{I} \cdot 0 \mathrm{~cm}$. vessels were used and the results obtained for March and April were necessarily less accurate. The measurements of percentage transmission, as adjusted against a blank with solvent, showed a strong absorption in the red and an even stronger one in the blue-violet. Results were, however, based on the minimum transmission in the red, since the shorter wave-absorption band was frequently masked by a general absorption occasioned by carotins and xanthophylls. The accuracy of the spectrophotometer was checked at 6563 and $486 \mathrm{I} \AA$. and found to be exact, using the hydrogen lamp.

\section{The SPeCtral Absorption CuRves}

In Fig. I the maximum absorption percentage of the red absorption band at $635 \mathrm{~m} \mu$ is plotted against the concentration of the commercial chlorophyll in $\mathrm{mg}$. $/ 1$. The relation is strictly rectilinear up to $4.0 \mathrm{mg}$. $/ 1$, and by 8.0 has fallen to $3 \mathrm{I} \cdot 8 \%$ against 35.8 for rectilinearity. It would appear from the position of 
the band maximum that the preparation contained both chlorophyll $a$ and $b$. Fig. 2 shows the absorption curves of two Chlorophyceae, in pure culture, for which we are indebted to Dr M. Parke. That for Chlorella I (by F. Gross) shows the chlorophyll absorption bands with minimum transmissions at 655 and $420 \mathrm{~m} \mu$, but for Chlamydomonas III (by Mrs Foyn), a solution of greater

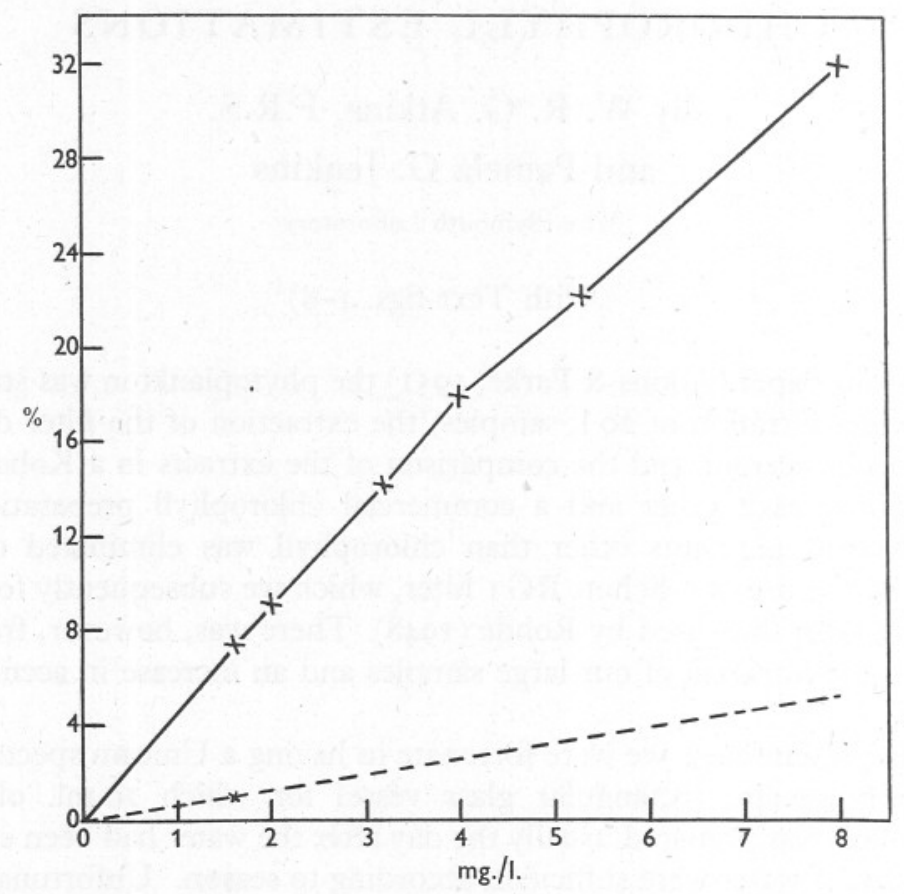

Fig. I. Percentage absorption at $635 \mathrm{~m} \mu$ (the position of minimum transmission in the red) for an $80 \%$ aqueous acetone solution of a dry commercial chlorophyll the concentrations of which are given on the abscissae in $\mathrm{mg}$./ $\mathrm{l}$., equivalent to ro $\mathrm{mg} . / \mathrm{m}^{3}$ when using Io $\mathrm{ml}$. plankton extract from $\mathrm{I} 1$. of sea water.

density also has a minimum at $655 \mathrm{~m} \mu$ but shows complete absorption before the $420 \mathrm{~m} \mu$ band has been reached. The same is shown by a strong solution, $320 \mathrm{mg}$. $/ 1$. of the commercial chlorophyll, which gave maximum absorption at $640 \mathrm{~m} \mu$.

In Fig. 3 is shown an extract of Hemiselmis rufescens, with sharp absorption maxima at 655 and $435 \mathrm{~m} \mu$, also the commercial chlorophyll, I6 mg./1., showing maxima at 635 and $4 \mathrm{IO} \mathrm{m} \mu$. The characteristic buff colour of the alga is due to the presence of a water-soluble crimson, which remains on the collodion or paper and is not dissolved by the aqueous acetone. The wider bands exhibited by the chlorophyll solution are probably due to admixture of the two forms. 


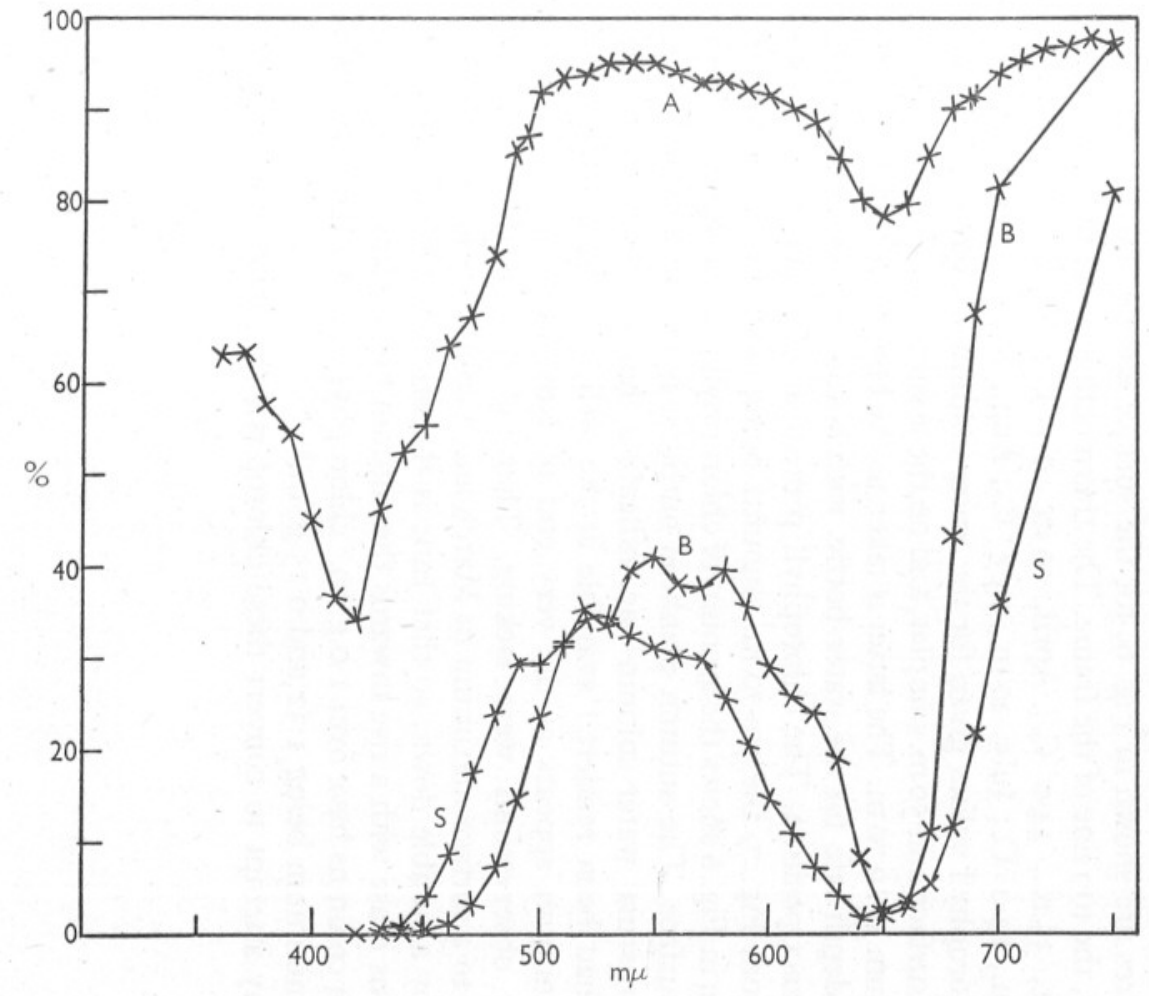

Fig. 2. Percentage transmissions from: $s$, a stock solution of a dry commercial chlorophyll in acetone, $90 \%$, with water; A, an $80 \%$ acetone extract of a culture of Chlorella I; and B, the same of Chlamydomonas III. The abscissae in this and the three following figures show wave-lengths in millimicrons.

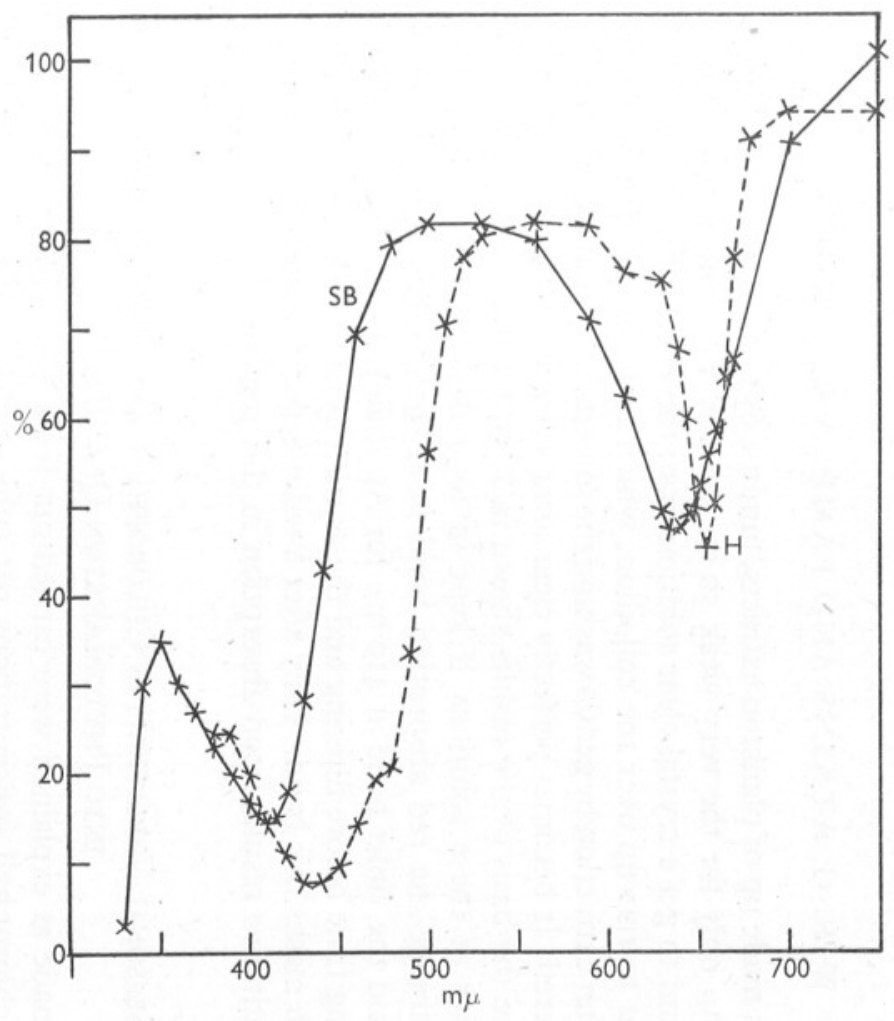

Fig. 3. Percentage transmissions from: $S B$, an $s / 20$ dilution of the chlorophyll; $\mathrm{H}$, an $80 \%$ acetone extract of a growth of Hemiselmis rufescens Parke, developed from water of station EI, 50 m., 7 January 1952 with a very little Nitzschia closterium. 
Fig. 4 is made up of plankton extracts, minima 655 and $435 \mathrm{~m} \mu$ for surface, and $650 \mathrm{~m} \mu$ only for the very weak $50 \mathrm{~m}$. sample. To avoid turbidity from fine clay and to get a crystal clear solution from the extract it is best to allow the solvent to rise up over the collodion, which rests on the side of a small beaker. After extraction by gentle washing the solvent is drained back into a tube and stoppered. It becomes perfectly clear after a few hours in the dark. Such extracts are the basis of the results shown in Figs. 6 and 7. Fig. 5 illustrates the stability of these solutions if kept in total darkness; after more than 3 years' storage the red absorption band is in each clearly a maximum at $650 \mathrm{~m} \mu$, and the violet band at $4 \mathrm{IO} \mathrm{m} \mu$ for April and June. The July sample stood a long time before filtering and the extract is obviously of a yellowish tint, which masks this band. Only after a tedious purification is it possible to base quantitative results upon absorption in this region.

\section{The Seasonal Variations in Chlorophyll and their Conversion Into Phytoplankton Quantities}

Extracts made as explained were carried out for a year, and the results are shown in chlorophyll concentrations per cubic metre in Fig. 6, surface and $50 \mathrm{~m}$., and at intermediate depths when a thermocline existed. These desirable samples were unfortunately not taken in the isothermal March water. The sea temperatures are shown in Fig. 6, for the surface above, and for the bottom just below, the top line of the frame. The thermoclines were found as follows: September, $35 \mathrm{~m} .$, I4 $.0^{\circ} \mathrm{C}$; April, Io m., 9. $7^{\circ} \mathrm{C}$; May, Io m., II $\cdot 7^{\circ} \mathrm{C}$; June, I5 m., I4.0 $.0^{\circ}$.; July, 20 m., I5. $8^{\circ}$ C.; Aug., 20 m., I5.6 $6^{\circ}$ C.

The chlorophyll values given for the water column are based on the mean values for surface and $50 \mathrm{~m}$. samples, and on the assumption that the water was uniform from 50 to $70 \mathrm{~m}$. The latter is taken as the bottom at station E I, but is actually a depth safe for the water-bottle, with bottom 72-74 m. according to tide and exact position. The chlorophyll present at intermediate depths was read off from Fig. 7, the $50-70 \mathrm{~m}$. amounts being calculated as before. The broken line in Fig. 6 shows the amount of chlorophyll in the column per square metre of surface. The autumn plankton outburst is in late September in an almost isothermal water column-an indication that the deep water mineral nutrients had been rendered available at the well illuminated depths. The winter minimum appears at the very end of November, possibly because December observations were lacking. There is then a rise, steep after February, to a surface maximum in March and a column maximum in April, followed by a tumble down, so that June is the minimum for the year. The observations cease with a rise towards the autumn high. Thus the September and March columns have over $\mathrm{I} \cdot \mathrm{O} \mathrm{g} . / \mathrm{m} .^{2}$ chlorophyll, the April maximum and the June minimum being $\mathrm{I} \cdot 32$ and $0.15 \mathrm{~g} . / \mathrm{m}{ }^{2}$.

One may attempt to convert these chlorophyll quantities into weights of 


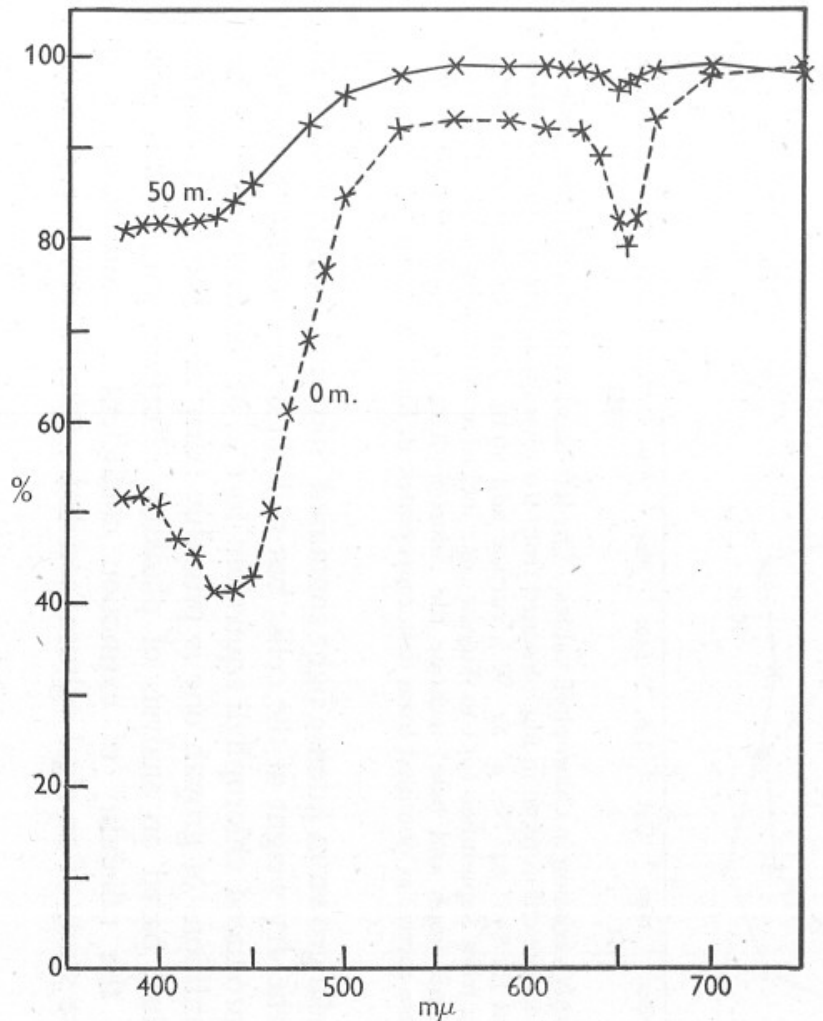

Fig. 4. Percentage transmissions given by extracts from plankton, collodion filtered from $\mathrm{O}$ and $50 \mathrm{~m} .21$. samples of water from station EI, II March I952.

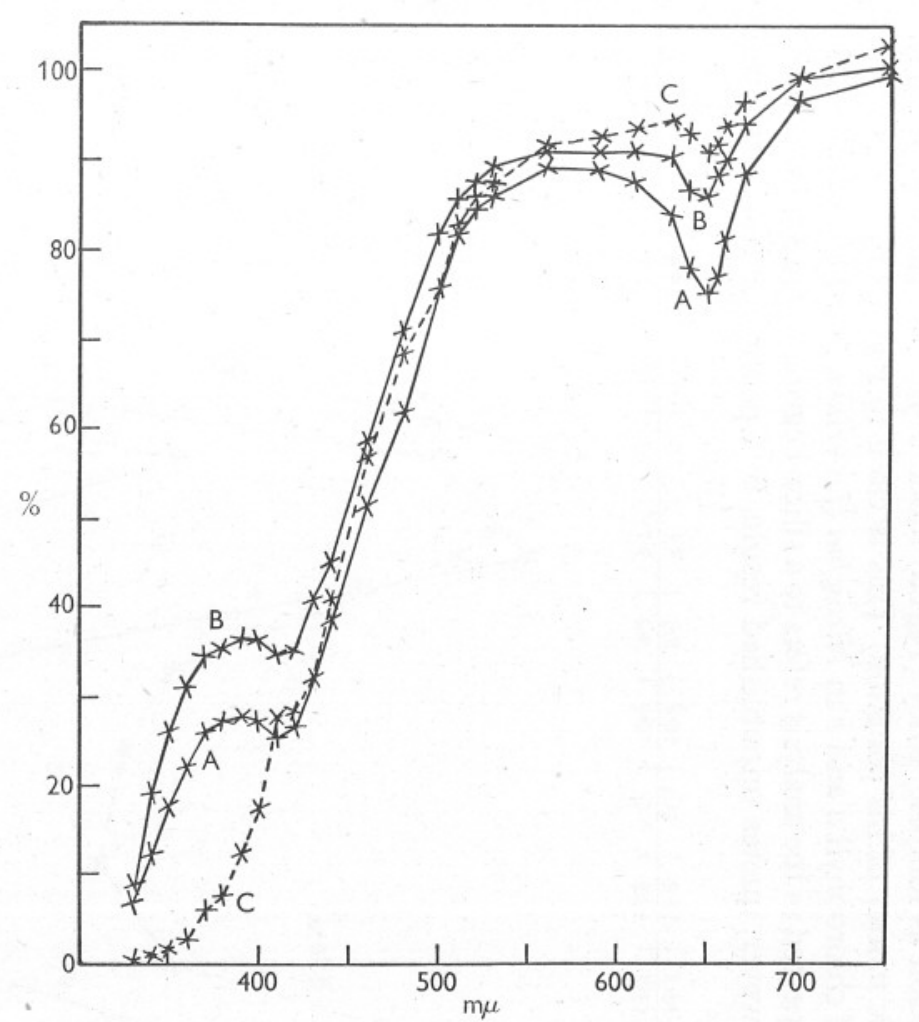

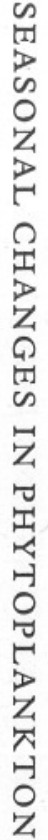

Fig. 5. Percentage transmissions given by extracts qualitatively similar to those of Fig. 4, but from about 201 . samples through paper using larger volumes of aqueous acetone. Those from station $\mathrm{E}_{\mathrm{I}}$, surface, were for April (A), June (B) and July (C), I949. There was delay in filtering and samples were stored in the dark for over 3 years. 
phytoplankton as follows. Riley (I94I $a$ ) found $2.91 \%$ of chlorophyll in the dry organic matter of his plankton. This is close to Pace's (I94I) $2 \cdot 32 \%$ for the sum of chlorophyll $a$ and $b$ in Nitzschia closterium, in which a lower value is to be expected as the analysis refers to a silica-bearing organism only. Strain (195I), however, quotes unpublished results by Spoehr and Milner showing

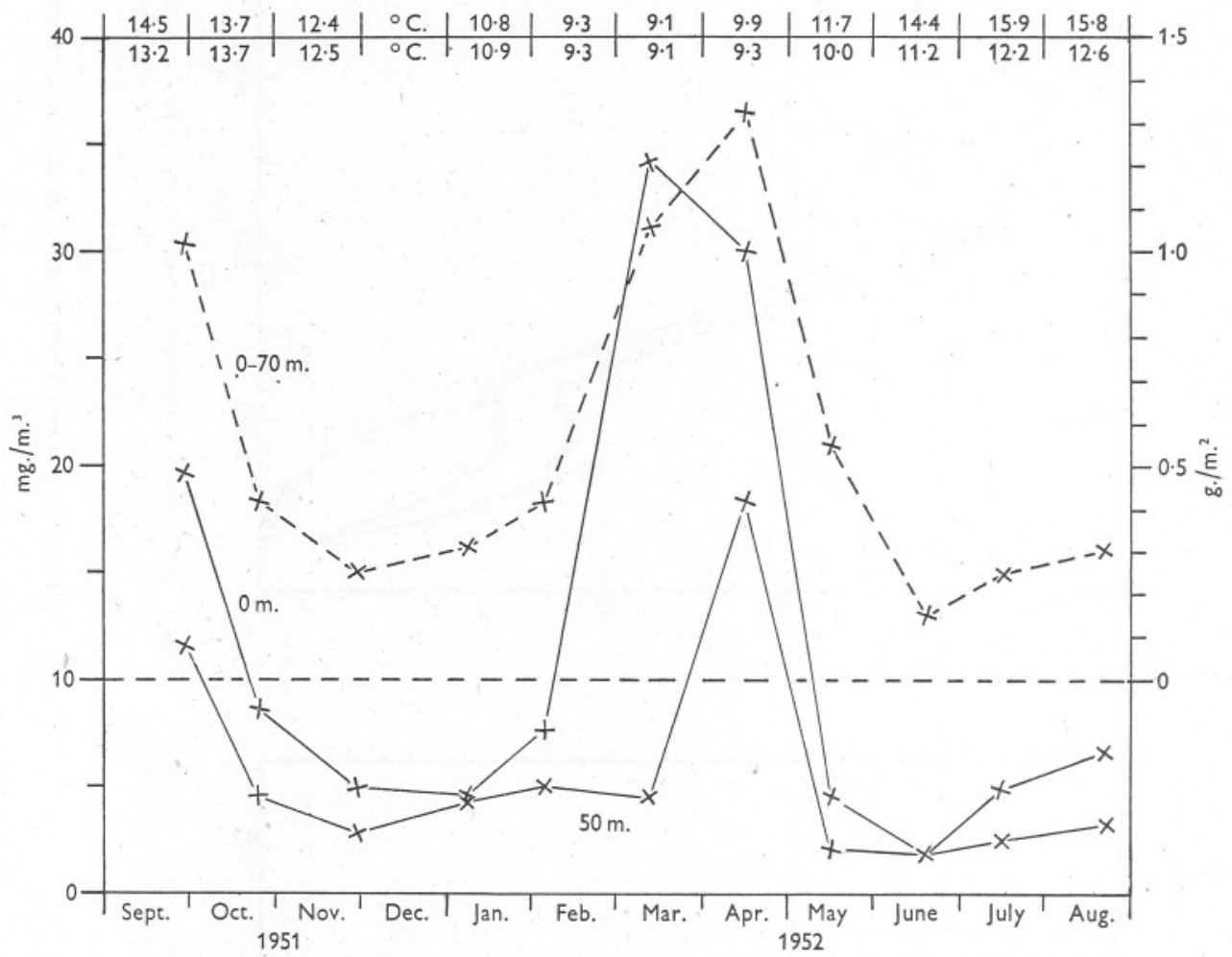

Fig. 6. Monthly variation in chlorophyll values. The left-hand ordinates (for continuous line graphs) denote chlorophyll in mg. obtained from the phytoplankton of $\mathrm{I} \mathrm{m} .^{3}$ of sea water at station EI $\left(50^{\circ} 02^{\prime} \mathrm{N} ., 4^{\circ} 22^{\prime} \mathrm{W}\right.$.), surface and $50 \mathrm{~m}$. The abscissae show dates of sampling from September I95I to August 1952 inclusive. The right-hand ordinates (for broken line graph and base) indicate the chlorophyll in the water column, $0-70 \mathrm{~m}$., per square metre, as obtained from data represented in this figure and Fig. 7.

that Chlorella grown in intense light contained chlorophyll equivalent to only $0.03 \%$ of the dry weight of the cells; but in light of low intensity, the same organism produced chlorophyll equivalent to $6 \%$ of the dry weight. Under normal conditions of growth one is probably fairly near the truth in taking Riley's value, based on analysis of plankton. Furthermore, Rohde, when discussing the reliability of extinction coefficient measurements in the quantitative study of an algal culture, concludes with 'if possible, therefore, 
one should carry out counts of the cell or colony concentration and determinations of the chlorophyll content in parallel with the photometric determinations'. Taking $2.91 \%$ of chlorophyll gives a factor 34.5 by which the weight of dry matter may be found from the pigment. To convert to wet weight the dry weight is assumed to be $20 \%$ (Atkins, I923), as was done in the calculation of the phytoplankton crop from phosphate consumption. When one adds

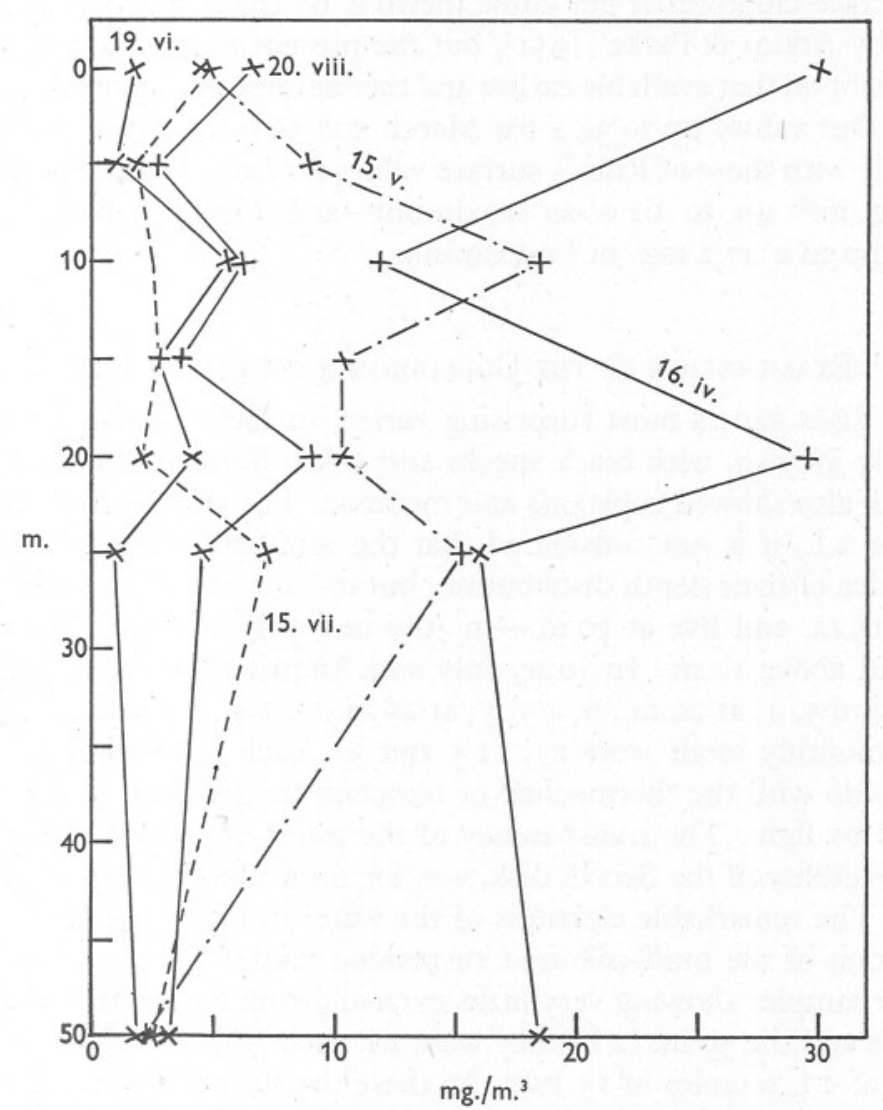

Fig. 7. Variation in chlorophyll values (as mg. $/ \mathrm{m}^{3}$ ) with depth of sampling (metres) on five dates in 1952 .

together the wet weight of phytoplankton as found for the II months, and for the missing December observation takes the mean of November and January, one arrives at $\mathrm{I} \cdot 09 \mathrm{~g}$. as the content in the column. This may be compared with the value found from phosphate in $1923, \mathrm{I} \cdot 4 \mathrm{~g}$.; and in the less rich water observed more recently Atkins has found for 1948 a consumption, indicating a production, of $84 \%$ of the I923 value, namely I.I7. The actual quantity of phosphate available in 1948 was only $75 \%$ of the 1923 value. Were the 
utilization less efficient than in 1948 and proportional to the amount available in winter (for which see the discussion in the accompanying paper on phosphate), the sum of the phytoplankton produced as a minimum value would be $\mathrm{I} \cdot 05 \mathrm{~g}$. This is close enough to the yearly total of the monthly standing crop to suggest that this must be eaten almost as fast as it is produced.

The surface chlorophyll per cubic metre is on the whole greater than that recorded by Atkins \& Parke (I95I), but the present method appears to be an improvement on that available earlier and the samples were more expeditiously handled. Our values up to $34 \cdot 2$ for March and $30 \cdot 0$ for April I952 are quite comparable with those of Riley's surface values for Long Island Sound (I94I $a$ ) $-17.4 \mathrm{mg}$. $/ \mathrm{m}^{3}$ up to 62.0 as maximum-and Georges Bank (I94I b) 5.6 mean up to a $27.2 \mathrm{mg} . / \mathrm{m} .^{3}$ maximum.

\section{Examination of the Collodion 4 CM Filter Disks}

The filter disks gave a most surprising variety in their intensity. The colour was usually greyish, with black specks and a few fibres visible with a handlens, which also showed copepods and medusae. The volume filtered being so small, I or 21 ., it is not considered that the numbers observed can give an accurate idea of their depth distribution, but in June one medusa per litre was found at $15 \mathrm{~m}$. and five at $20 \mathrm{~m}$. - in July one only at $15 \mathrm{~m}$. No copepods were found above $10 \mathrm{~m}$. In June, July and August at Io $\mathrm{m}$. we got $\mathrm{I}, \mathrm{O}, \mathrm{I}$; at $15 \mathrm{~m} ., 7,0.5,2$; at $20 \mathrm{~m} ., 6,4.5,5$; at $25 \mathrm{~m} ., 8,3.5,0.5$; and at $50 \mathrm{~m} ., 5,3$, 0.5 . The monthly totals were 27, II.5 and 9 . Such a distribution can have nothing to do with the thermocline or temperature gradient, and is probably influenced by light. The transparency of the water, indicated roughly by the depth of visibility of the Secchi disk, was for these months respectively 23 , I8 and II $\mathrm{m}$. The remarkable clearness of the water in June is perhaps related to the collection of the mud-coloured suspended matter in the surface sample, the deeper samples showing very little, even allowing for the fact that save for the surface and the $50 \mathrm{~m}$. (2 1.) they were I l. each (Fig. 8). Fig. 8 also shows the series of 21 . samples of 15 July. In these the surface and $50 \mathrm{~m}$. are rather similar, and $25 \mathrm{~m}$. shows up as darkest in the photograph. Visually it was not so but had a yellowish tint, as had also $50 \mathrm{~m}$. to a lesser extent.

\section{The Botanical Composition of the Phytoplankton at StaTion E I}

This station has been visited for many years and records of its phytoplankton have been published in the Bulletin Planktonique up to 1912 and summarized later by Ostenfeld (I93I) but the following observations may be of interest. $\mathrm{E}_{\mathrm{I}}$ is Io miles S.W. of the Eddystone and the list published by Harvey, 


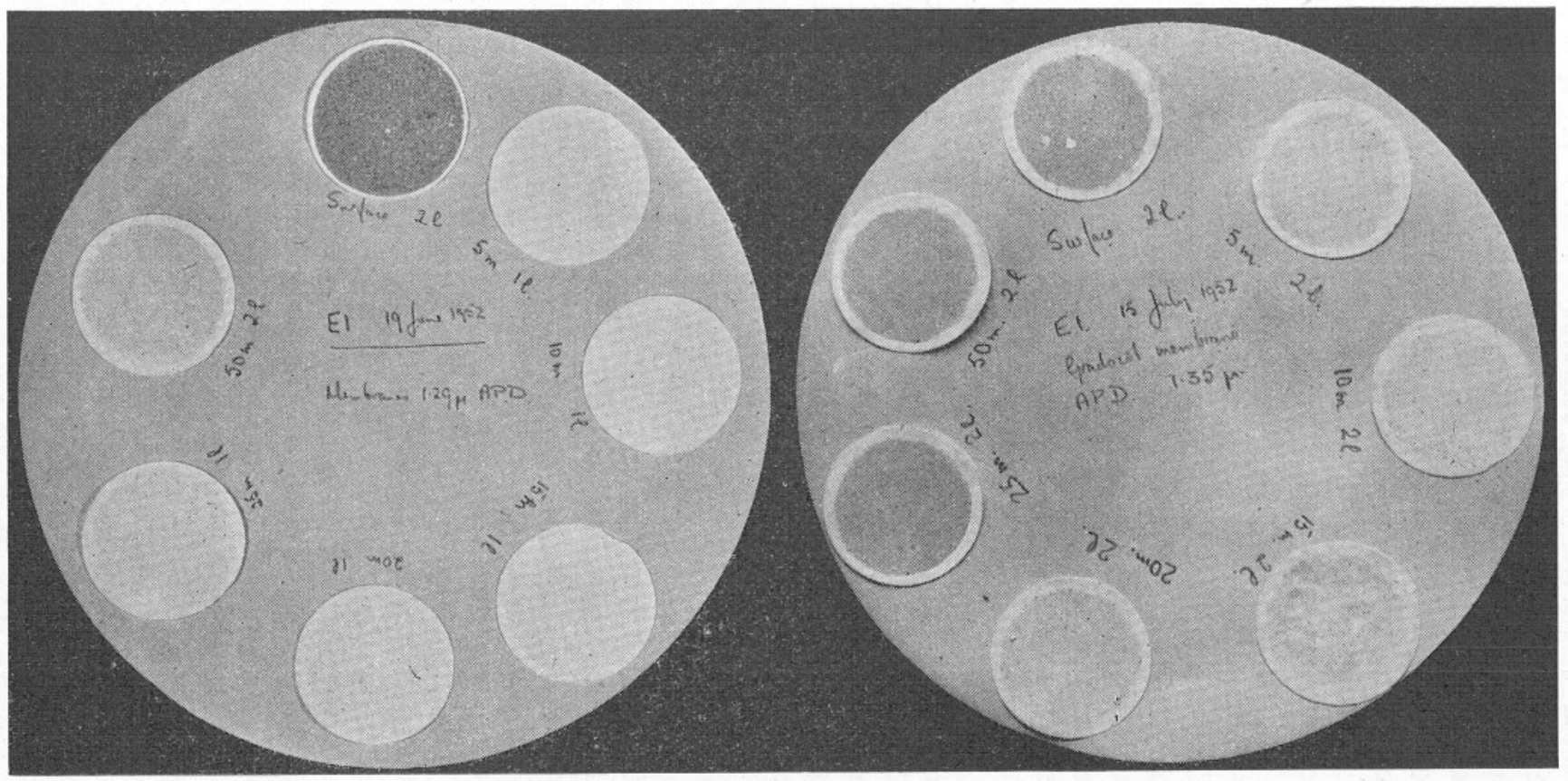

Fig. 8. View of the collodion filter disks with collected matter. Series for I9 June (left) and I5 July I952 (right). 
Cooper, Lebour \& Russell (I936) concerns station L4, depth $50 \mathrm{~m}$. and I4 miles nearer shore, about $5 \frac{1}{2}$ miles from Plymouth breakwater. We had no plankton hauls and no time to count the algae in the filter disks, but a qualitative examination was made as follows. Samples of the water, Ioo or $250 \mathrm{ml}$., were placed in conical flasks enriched with Miquel's solution and exposed in a south window in winter or a north window in late spring and summer. Some, but probably not all, of the phytoplankton multiplied rapidly, and periodical examinations were made. The plus signs in Tables I and II are an attempt to indicate the relative amounts found in the earlier stages of the cultures; + , present; ++ , more frequent +++ , plentiful; ++++ , very plentiful: Though sampling was begun in September it was only, unfortunately, on 8 February 1952 that the enriched samples were exposed in the window; before that the Winchester bottles had diffuse light in a south room. The earlier dates are probably too sparsely represented. No attempt has been made as yet to represent the depth distribution.

Table I shows the Bacillariophyceae found, twenty species, of which Nitzschia closterium, Melosira Borreri and Navicula sp. were the most regular in occurrence. As compared with the $\mathrm{L}_{4}$ list of $\mathrm{I} 935$ it is remarkable that Nitzschia closterium then appeared in negligible amount in March, April and September. N. delicatissima and N. seriata appear on both lists. Paralia sulcata, common at $\mathrm{L}_{4}$, was only found once at E I. Guinardia flaccida, which occurred regularly at $\mathrm{L}_{4}$, was absent from $\mathrm{E}_{\mathrm{I}}$, as were also over sixteen other species. Found at EI, but not mentioned for $\mathrm{L}_{4}$, were Fragilaria sp., Grammatophora marina, Melosira sp., Rhizosolenia alata f. genuina and R. hebetata f. semispina.

Table II lists the Chlorophyceae, Chrysophyceae, Cryptophyceae, Dinophyceae and Miscellaneous found as for Table I. None of the Chlorophyceae are recorded in the $\mathrm{L}_{4}$ list, yet in our cultures they were the striking feature in most of the April-August samples, save the $0 \mathrm{~m}$. samples, the $5 \mathrm{~m}$. for April and the $50 \mathrm{~m}$. sample for July, which were brown with diatoms; also, the $20 \mathrm{~m}$. July sample had a very minute bacterium (with one flagellum visible) which produced a pink colour, modified to buff by a Cryptomonad. This organism became conspicuous in the ro $\mathrm{m}$. sample later. In several of the series $20 \mathrm{~m}$. was noticeably behind the others in development.

Of the Chrysophyceae, Phaeocystis was recorded from $\mathrm{L}_{4}$ and has often been found at EI, but it was absent from our samples. Two others, however, were present at $\mathrm{E}_{\mathrm{I}}$ though not at $\mathrm{L}_{4}$ : Coccolithophora sp., very plentiful in July and August samples, and a member of the Chrysomonadaceae.

The Cryptophyceae afforded two records, in July a species of the Cryptomonadaceae and most remarkably from $50 \mathrm{~m}$., of 7 January, we obtained an almost pure growth of Hemiselmis rufescens Parke, which was identified by its appearance and the scarlet pigment insoluble in $80 \%$ acetone which was left on the collodion. Its chlorophyll with possibly other pigments gave the curve 
TABLE I. AlgaE IDENTIFIED IN CHEMICALLY ENRICHED SAMPLES.

BACILLARIOPHYCEAE :

Asterionella japonica Cleve \& Möller* Cerataulina Bergonii $\mathrm{H}$. Pérag. $†$

Chaetoceros sp.

Coscinodiscus $\mathrm{sp}$.

Fragilaria sp.

F. oceanica Cleve

Grammatophora marina Kütz.

Leptocylindricus danicus Cleve

Melosira borreri Greville

Navicula sp.

Nitzschia closterium $\mathrm{Ehr}$

N. delicatissima Cleve*

N. seriata Clevet

Paralia sulcata Ehr.

Rhizosolenia alata Brightw. f. genuina Gran.

$R$. f. indica Péragallo

$R$. hebetata (Bail.) f. semispina Hensen $\neq$

Skeletonema costatum Grevilleł

Thalassiosira gravida Cleve

Thalassiothrix (Thalassionema) Nitzschiodes

Grun. $\neq$

$$
\begin{array}{cccc}
27 . \text { ix. 51 } & \text { 24. x. 51 } & \text { 7. i. 52 } & \text { 5. ii. 52 } \\
: & : & : & : \\
+ & : & ++ & : \\
: & : & : & : \\
: & : & : & : \\
++ & ++ & : & : \\
+++ & +++ & ++++ & +++ \\
\cdot & : & : & : \\
: & : & : & ++ \\
: & : & : & : \\
: & : & : & :
\end{array}
$$

II. iii. 52

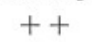

I6. iv. 52

I5. v. 52

.

i

$+\dot{+}$

$++$

$+\dot{+}+$

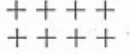

++++
++++

:

$++$

.

$\dot{+}$

$+\dot{+}$

$+$

.

;

+
++
++ $\begin{array}{lll}\text { I9. vi. } 52 & \text { 15. vii. } 52 & 20 . \text { viii. } 52\end{array}$

$+++$
$:$
$\vdots$
$\vdots$
++
+++
+++

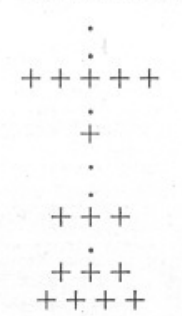

$++$

$+$

$++$

$+$

$+$

$++$

$++$

$+\dot{+}+$

$+$

$\begin{array}{ll}\text { + } & ++ \\ ++\end{array}$

* For southern part of North Sea or Flemish area.

- Indicates species similarly listed for eastern part.

Indicates species listed by Ostenfeld (I93I) as common in western part of English Channel.

September, October, January and February samples enriched and exposed in window, 8 February 1952; the same holds for Table II. 
TABle II. Algae identified in ChemiCally ENRiched SAMPles.

CHLOROPHYCEAE :

Chlamydomonas sp.

Chorella sp.

Endoderma sp.

Halosphaera viridis Schmitz

Platymonas tetrahele West.

Pyramimonas sp. Schmarda

Stichococcus bacillaris Naeg.

Ulothrix subflaccida Wille

CHRYSOPHYCEAE :

Chrysomonadaceae sp.

Coccolithophora sp.

CRYPTOPHYCEAE :

Cryptomonadaceae sp.
Hemiselmis rufescens Parke

DINOPHYCEAE :

Prorocentrum micans $\mathrm{Ehr}$.

Miscellaneous:

Flagellates, colourless

Amoebae

Ciliates, colourles

Bacterium, pink
27. ix. 5 I

7. i. 52

5. ii. 52

II. iii. 52

I6. iv. 52

I5. v. 52

I9. vi. 52

15. vii. 52

20. viii. 52

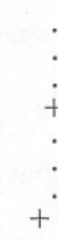

$:$
$\dot{+}$
$\dot{+}$
+

$++$

$+++$

$++$

$+++$

$++\dot{+}+$

$+\dot{+}+$

+++
+++

$+\dot{+}+$

$+$

$+$

++
+++

.

$++\dot{+}$
$+$
$+++$

$++$

$+\dot{+}$

$+$

$+$

$+$

++
+++

$++\dot{+}+$

$++$

$+++$

$+\dot{+}+$
++++
$++$
$+++$ $++$ 
shown in Fig. 3. Of the seven Dinophyceae in the $\mathrm{L}_{4}$ list only Prorocentrum micans was observed in the E I cultures.

We desire to express our indebtedness to Miss D. Ballantine, Dr M. V. Lebour, Dr T. J. Hart and Dr M. Parke for much help in the identifications, also our thanks to Mr F. A. J. Armstrong for filtering the samples and for temperature observations and to Mr A. E. Stoate and Mr A. Mattacola for the photographs. Finally, for these and many other sea-water samples and Secchi disk observations we have pleasure in thanking Lieut.-Comdr. C. A. Hoodless, D.S.C., R.N.R., and the crew of the R.V. Sabella.

\section{SUMMARY}

Chlorophyll from the phytoplankton at station EI was examined from September I95I till August I952, from o to $50 \mathrm{~m}$. The minimum was in June, $\mathrm{I} .8 \mathrm{mg} . / \mathrm{m}^{3}$, and the maximum 34.2 in March, both surface samples. The maximum $50 \mathrm{~m}$. sample contained $\mathrm{r} 8.4 \mathrm{mg} . / \mathrm{m} .^{3}$ in April. The winter minima were 4.6 and 4.3 , surface and bottom, in November. Converted to water column $\left(70 \mathrm{~m}\right.$.) values, over $\mathrm{I} \cdot 0 \mathrm{~g} . / \mathrm{m} .{ }^{2}$ is obtained for the wet weight of phytoplankton for September and March, the April maximum and the June minimum being $\mathrm{I} .32$ and $0.15 \mathrm{~g} . / \mathrm{m} .^{2}$. A comparison with the production obtained from phosphate analyses suggests that the phytoplankton crop each month is rapidly devoured.

Exact proportionality was found between concentration and absorption in a chlorophyll band up to $4.0 \mathrm{mg}$./1. and a moderate error up to $8.0 \mathrm{mg}$. $/ 1$. The spectral absorption curves have been given for pure cultures of phytoplankton and for cells filtered out of sea water. The chlorophyll in such extracts, made with $80 \%$ acetone, is stable when kept in total darkness.

The collodion disks containing suspended clay and the algal cells may show a surprising variation in their colour intensity, from dark grey to a very faint tint, even though obtained from sea water about 20 miles from land and over $70 \mathrm{~m}$. in depth. The surface may be far darker than 5 , Io or $15 \mathrm{~m}$. samples.

The botanical composition of the water was studied by allowing the algae to multiply in diffuse light after enriching the water chemically. Eight species of Chlorophyceae, and one species each of the Chrysophyceae and Dinophyceae were recorded. Of the Cryptophyceae one winter sample from $50 \mathrm{~m}$. gave a nearly pure growth of Hemiselmis rufescens Parke. The diatoms Melosira borreri, Nitzschia closterium and Navicula sp. occurred commonly. 


\section{REFERENCES}

Atkins, W. R. G., I923. The phosphate content of fresh and salt waters in its relationship to the growth of the algal plankton. Fourn. Mar. Biol. Assoc., Vol. I3, pp. II9-50.

AtKINS, W. R. G. \& PARKe, M., I95I. Seasonal changes in the phytoplankton as indicated by chlorophyll estimations. Fourn. Mar. Biol. Assoc., Vol. 29, pp. 609-18.

HaRvey, H. W., Cooper, L. H. N., Lebour, M. V. \& Russell, F. S., I936. Plankton production and its control. Fourn. Mar. Biol. Assoc., Vol. 20, pp. 407-4I.

Ostenfeld, C. H., I931. Publ. Conseil internat. pour exploration de la mer. Résumé planktonique Iv.

PACE, N., I94I. Pigments of the marine diatom Nitzschia closterium. Fourn. Biol. Chem., Vol. I40, pp. 483-89.

Riley, G. A., I94I $a$. Plankton studies. III. Long Island Sound. Bull. Bingham Ocean. Coll., Vol. 7 (3), pp. I-93.

I94I b. Plankton studies. IV. Georges Bank. Bull. Bingham Oceanogr. Coll., Vol. 7(4), pp. I-73.

RoHDE, W., I948. Environmental requirements of freshwater plankton algae. Symbolae Bot. Uppsaliensis, Bd. x, pp. I49.

Strain, H. H., I95I. The pigments of algae. Manual of Phycology, ch. I3. Waltham, Mass., U.S.A. 